\title{
Analisis kesulitan mahasiswa dalam menyelesaikan soal Geometri berdasarkan taksonomi bloom dan alternatif pemecahannya
}

\section{Muhammad Ridlo Yuwono ${ }^{1}$}

\begin{abstract}
Abstrak: Penelitian ini bertujuan untuk mendiagnosis kesulitan mahasiswa dalam menyelesaikan soal geometri berdasarkan Taksonomi Bloom dan alternatif pemecahannya. Jenis penelitian ini adalah penelitian deskriptif dengan menggunakan pendekatan kualitatif. Pengambilan data dilakukan dengan metode tes dan wawancara. Peneliti mengambil tiga subjek untuk diwawancarai. Hasil penelitian ini menunjukkan bahwa terdapat empat jenis kesulitan yaitu: 1). Pada tingkat pemahaman, mahasiswa kesulitan memahami konsep tinggi dan alas jajargenjang. Alternatif pemecahannya dengan menggunakan model penilaian Assessment for Learning (AfL); 2). Pada tingkat penerapan, mahasiswa kesulitan menerapkan konsep kesebangunan bangun datar untuk menyelesaikan soal. Alternatif pemecahannya dengan model penilaian Assessment for Learning (AfL); 3). Pada tingkat analisis, mahasiswa kesulitan membuktikan rumus luas daerah segitiga dengan menggunakan pendekatan luas daerah jajargenjang. Alternatif penyelesaiannya dengan pembelajaran Process Oriented Guided Inquiry Learning (POGIL); 4). Pada tingkat evaluasi, mahasiswa kesulitan dalam memberikan penilaian terhadap suatu permasalahan disertai dengan alasan yang logis. Alternatif pemecahannya adalah dengan pembelajaran yang menggunakan model penilaian peer-assesment.
\end{abstract}

\section{Kata kunci: Kesulitan; Geometri; Taksonomi Bloom; Alternatif Pemecahan}

Abstract: This study aims to diagnose undergraduate student's difficulties in solving geometry problems based on Bloom's Taxonomy and find alternative solutions. This study is a descriptive study using qualitative approach. Data collection is conducted through test and interview. The subject of this study is 3 students. There are four difficulties found in this study, they are: 1). At the level of comprehension, the students are difficult to comprehend the concept

\footnotetext{
${ }^{1}$ Universitas Widya Dharma Klaten, Indonesia,ridloyuwono90@gmail.com
} 
of height and length of parallelogram. The alternative solution is to apply Assessment for Learning (AfL) model; 2). At the application level, the students have difficulty in applying the congruency concept of plane to solve the problem. The alternative solution is Assessment for Learning ( $\mathrm{AfL}$ ) model; 3). At the level of analysis, the students have difficulty in proving the formula of area of a triangle using parallelogram area. The alternative solution is to apply Process Oriented Guided Inquiry Learning (POGIL); 4.) At the evaluation level, the students have difficulty in providing assessment of a problem with a logical reason. The alternative solution is to use peer-assessment model of learning.

Keywords: Difficulties; Geometry; Bloom's Taxonomy; Alternative Solutions

\section{A. Pendahuluan}

Matematika merupakan ilmu dasar yang memegang peranan penting dalam kehidupan yang mempunyai karakter sebagai ilmu abstrak. Salah satu cabang matematika adalah geometri. Menurut Abdussakir (2010), geometri digunakan oleh setiap orang dalam kehidupan sehari-hari. Ilmuwan, arsitek, artis, insinyur, dan pengembang perumahan adalah sebagian kecil contoh profesi yang menggunakan geometri secara reguler. Tidak hanya pada siswa SD, SMP, dan SMA saja akan tetapi juga pada tingkat mahasiswa. Mahasiswa Program Studi Pendidikan Matematika Universitas Widya Dharma Klaten diwajibkan untuk mengambil mata kuliah geometri sesuai dengan kurikulum yang berlaku. Mahasiswa Pendidikan Matematika dipersiapkan untuk menjadi calon guru matematika yang handal dan professional, sehingga diwajibkan untuk menguasai kompetensi dasar pada setiap mata kuliah, termasuk mata kuliah geometri. Oleh karena itu, dosen dituntut untuk menyiapkan calon guru yang profesional melalui kegiatan perkuliahan.

Dalam penyampaian suatu materi perkuliahan, dosen harus memperhatikan tingkat kemampuan mahasiswa, mengetahui tingkat perkembangan kognitif mahasiswa dan bagaimana pengajaran harus dilakukan agar sesuai dengan tingkat-tingkat perkembangan kognitif mahasiswa. Menurut Piaget (2002), seseorang pada rentang usia 11 tahun 
ke atas berada pada taraf perkembangan operasi formal dengan ciri pokok perkembangan kognitif berupa hipotesis, abstrak, deduktif dan induktif, serta logis dan probabilitas.

Menurut Budiyono (2015), terdapat banyak penggolongan tujuan pembelajaran pada ranah kognitif, salah satu diantaranya adalah penggolongan tujuan berdasarkan Taksonomi Bloom. Taksonomi Bloom tersebut telah direvisi oleh Anderson dan Kwarthowl. Anderson dan Kwarthowl (2001) mengemukakan bahwa dimensi dari proses kognitif dibedakan menjadi enam tingkatan, yaitu remember (mengingat), understand (memahami), apply (menerapkan), analysis (menganalisis), evaluation (menilai), dan create (mencipta).

Selain itu, dosen juga harus mengetahui kesulitan apa saja yang dialami oleh mahasiswa dalam mempelajari mata kuliah geometri. Tujuannya adalah supaya meminimalisir hambatan belajar mahasiswa untuk mencapai tujuan pembelajaran. Kesulitan yang dialami mahasiswa dapat diidentifikasi melalui kesalahan yang dilakukan pada saat mengerjakan soal mata kuliah geometri. Hasil penelitian Imswatama \& Muhassanah (2015) menyatakan bahwa kesulitan mahasiswa dalam meyelesaikan soal geometri analitik materi garis dan lingkaran adalah menghafal rumus yang digunakan untuk mengerjakan soal yang diberikan, kesulitan dalam menentukan langkah pengerjaan soal yang diberikan serta kesulitan dalam memahami maksud soal yang diberikan.

Hasil penelitian Yuliani dan Sumardi (2015) menunjukkan bahwa mahasiswa kesulitan dalam memahami konsep geometri, kesulitan menerapkan konsep, kesulitan memahami rumus, kesulitan menentukan langkah-langkah melukis, faktor lingkungan belajar dan sikap mahasiswa terhadap mata kuliah geometri bidang. Hasil penelitian Radita (2015) menunjukkan bahwa hasil diagnosis kesulitan diperoleh data bahwa (1) subjek yang mengalami kesulitan pada tahap mengingat tidak mampu menyebutkan rumus keliling segitiga dan salah menuliskan absis suatu titik, (2) subjek yang mengalami kesulitan pada tahap memahami merepresentasikan hanya sebagian titik-titik yang memenuhi sebagai titik sudut ketiga segitiga, (3) subjek yang mengalami kesulitan pada tahap menerapkan melakukan kesalahan dalam menggunakan konsep jarak dua titik untuk menyelesaikan soal, (4) subjek yang mengalami kesulitan pada tahap menganalisis tidak mampu mengidentifikasi bahwa persamaan yang 
dihasilkan merupakan persamaan elips, (5) subjek yang mengalami kesulitan pada tahap mengevaluasi tidak memeriksa apakah semua titik yang memenuhi persamaan merupakan solusi untuk titik sudut ketiga segitiga dan (6) subjek yang mengalami kesulitan pada tahap create tidak bisa mengerjakan soal dengan strategi yang berbeda.

Berdasarkan latar belakang masalah yang telah diuraikan, perlu dilakukan penelitian tentang jenis kesulitan yang dialami oleh mahasiswa dalam menyelesaikan soal mata kuliah geometri berdasarkan Taksonomi Bloom beserta alternatif penyelesaian untuk mengatasi jenis kesulitan tersebut.

\section{B. Metode Penelitian}

Jenis penelitian ini adalah penelitian deskriptif dengan menggunakan pendekatan kualitatif. Penelitian ini mendeskripsikan jenis-jenis kesulitan mahasiswa dalam menyelesaikan soal mata kuliah geometri berdasarkan Taksonomi Bloom beserta alternatif penyelesainnya. Subjek penelitian adalah mahasiswa Program Studi Pendidikan Matematika kelas IV B Tahun Akademik 2015/2016 yang terdiri dari 15 mahasiswa. Dari 15 mahasiswa diambil 3 subjek untuk diwawancarai. Ketiga subjek yang diambil adalah mahasiswa yang melakukan kesalahan terbanyak pada soal tes mata kuliah geometri berdasarkan Taksonomi Bloom serta mampu berkomunikasi secara baik. Subjek tersebut masing-masing diberi kode S1, S2, dan S3.

Teknik pengumpulan data pada penelitian ini menggunakan metode tes dan wawancara. Pada tes geometri, data yang diharapkan berupa hasil pekerjaan mahasiswa langsung pada lembar soal berserta langkahlangkahnya. Tujuan tes geometri adalah untuk mengetahui kesulitan mahasiswa dalam menyelesaikan soal mata kuliah geometri berdasarkan Taksonomi Bloom. Wawancara dilaksanakan berdasarkan pedoman wawancara yang telah disusun. Data yang diperoleh berupa jawabanjawaban subjek penelitian secara langsung mengenai tes geometri. Jawaban-jawaban subjek penelitian berdasarkan wawancara digunakan sebagai triangulasi.

Instrumen pada penelitian ini adalah peneliti (sebagai intrumen utama), tes geometri, dan pedoman wawancara. Peneliti mengembangkan tes geometri serta melakukan wawancara terhadap 
subyek penelitian. Data yang diperoleh dari penelitian disahkan melalui triangulasi kemudian peneliti menganalisis data tersebut (Moleong, 2007).

Tes geometri ini merupakan tes yang dirancang untuk keperluan mendiagnosis kesulitan mahasiswa dalam menyelesaikan soal mata kuliah geometri. Berdasarkan hasil tes tersebut akan diidentifikasi jenis kesulitan siswa berdasarkan Taksonomi Bloom. Dari enam tingkatan yang ada, hanya diambil empat, yaitu: pemahaman, penerapan, analisis, dan evaluasi. Tingkatan mengingat tidak diambil, dikarenakan berdasarkan pengamatan saat kuliah dan ujian, mahasiswa tidak terbiasa dengan soal hafalan untuk mata kuliah geometri. Tingkatan mengkreasi juga tidak diambil, dikarenakan pada mata kuliah geometri tidak difokuskan untuk menemukan teori atau teorema baru.

Pedoman wawancara dirancang untuk mempermudah peneliti dalam menggali informasi siswa mengenai tes diagnostik yang berkaitan dengan geometri. Pedoman wawancara yang digunakan berdasarkan hasil analisis dari jawaban tes geometri.

\section{Temuan dan Pembahasan}

Tabel 1 berikut menyatakan soal tes geometri beserta tingkatan kognitif berdasarkan Taksonomi Bloom.

Tabel 1. Soal Tes Geometri

\begin{tabular}{|c|l|c|}
\hline No. & \multicolumn{1}{|c|}{ Soal } & $\begin{array}{c}\text { Tingkatan } \\
\text { Kognitif }\end{array}$ \\
\hline 1 & $\begin{array}{l}\text { Perhaikan gambar berikut! Terdapat berapa } \\
\text { pasangan alas dan tinggi jajargenjang KLMN? } \\
\text { Sebutkan dan sertai dengan gambarnya! }\end{array}$ & $\begin{array}{c}\text { comprehension } \\
\text { (C2) }\end{array}$ \\
\hline 2 & $\begin{array}{l}\text { Sebuah karton berukuran tinggi } 30 \mathrm{~cm} \text { dan lebar } 20 \mathrm{~cm} . \\
\text { Doni menempelkan sebuah foto sehingga sisa karton di } \\
\text { sebelah kiri, kanan, atas foto adalah } 2 \mathrm{~cm} \text {. Jika foto dan } \\
\text { karton sebangun, tentukan sisa karton di bawah foto! }\end{array}$ & application (C3) \\
\hline
\end{tabular}


Beтa

\begin{tabular}{|c|l|c|}
\hline No. & \multicolumn{1}{|c|}{ Soal } & \multicolumn{1}{|c|}{$\begin{array}{c}\text { Tingkatan } \\
\text { Kognitif }\end{array}$} \\
\hline 3 & $\begin{array}{l}\text { Buktikan bahwa rumus luas daerah segitiga Luas = } \\
\frac{1}{2} \times \text { alas } \times \text { tinggi dengan menggunakan } \\
\text { pendekatan luas daerah jajargenjang! }\end{array}$ & analysis (C4) \\
\hline 4 & $\begin{array}{l}\text { Terdapat dua pendekatan dalam menemukan rumus } \\
\text { luas daerah jajargenjang. Pendekatan yang pertama } \\
\text { dengan menggunakan luas daerah persegipanjang. }\end{array}$ & evaluation (C5) \\
$\begin{array}{l}\text { Pendekatan yang kedua dengan menggunakan luas } \\
\text { daerah segitiga. Menurut Anda, pendekatan } \\
\text { manakah yang lebih efektif untuk disampaikan } \\
\text { kepada peserta didik SMP? Jelaskan alasan Anda! }\end{array}$ & \\
\hline
\end{tabular}

Berikut jawaban mahasiswa dalam mengerjakan soal tes geometri beserta analisisnya.

a. Jawaban Soal Nomor 1

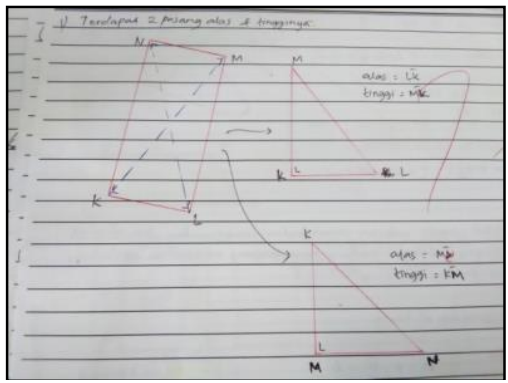

Gambar 1. Kesulitan S1 pada Jawaban No. 1

Berdasarkan Gambar 1 subjek S1 menyebutkan terdapat dua pasangan alas dan tinggi jajargenjang. Akan tetapi caranya masih belum tepat. Subjek S1 justru membuat gambar jajargenjang menyerupai bentuk persegipanjang. Persegipanjang tersebut dibuat diagonalnya untuk membuat dua segita sikusiku. Berdasarkan segitiga siku-siku tersebut, kemungkinan S1 dapat mengetahui alas dan tinggi jajargenjang yang ditanyakan.

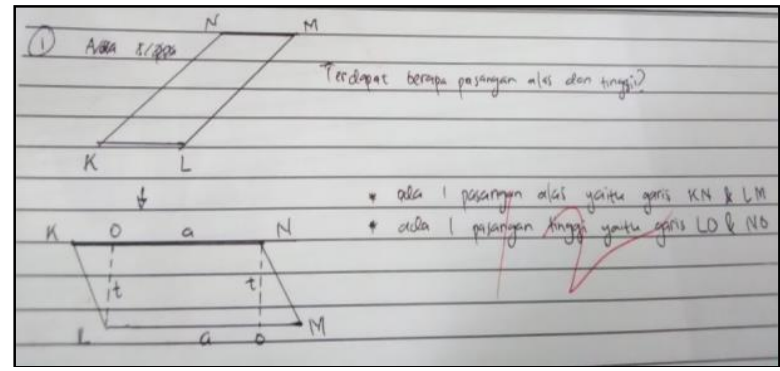

Gambar 2. Kesulitan S2 pada Jawaban No. 1 
Berdasarkan Gambar 2 subjek S2 menyebutkan terdapat dua pasangan alas dan tinggi jajargenjang KLMN. Dua pasangan yang disebutkan sebenarnya sudah tepat, tetapi kurang lengkap.

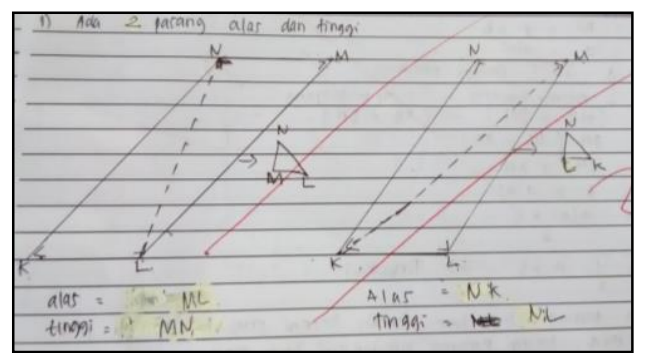

Gambar 3.Kesulitan S3 pada Jawaban No. 1

Berdasarkan Gambar 3 subjek S3 menyebutkan terdapat dua pasangan alas dan tinggi jajargenjang KLMN. Akan tetapi yang disebutkan masih belum tepat. Kemungkinan S3 membuat garis tinggi dengan bantuan diagonal jajargenjang yang kemudian dibuat segitiga siku-siku.

Berdasarkan jawaban subjek S1, S2, dan S3, diperoleh kemungkinan bahwa subjek masih belum bisa memahami konsep alas dan tinggi secara benar. Mereka kelihatan masih bingung menggambar garis tinggi pada jajargenjang yang sudah diketahui. Hal tersebut dapat dilihat dari cara mereka menggambarnya. Dua diantaranya memodifikasi gambar jajargenjang yang terdapat pada soal dan cara tersebut pun masih belum benar.

b. Jawaban Soal Nomor 2

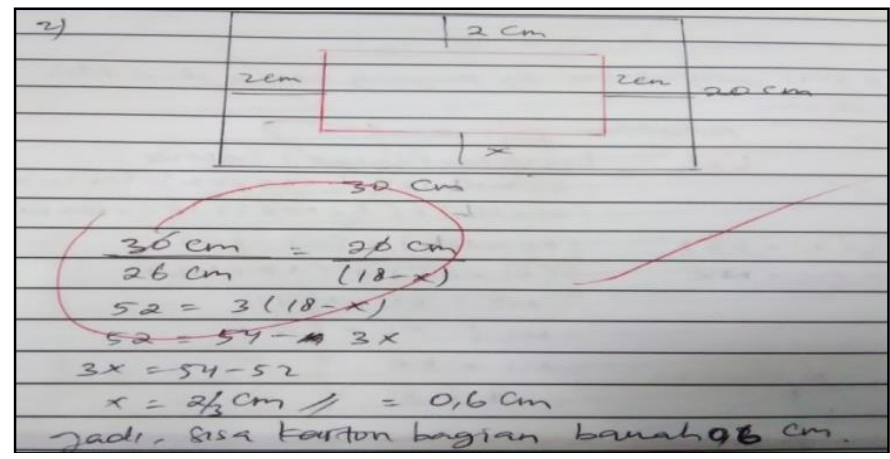

Gambar 4. Kesulitan S1 pada Jawaban No. 2

Berdasarkan Gambar 4 subjek S1 belum menggambar model bangun yang diminta pada soal secara benar. Kemungkinan S1 belum memahami soal dengan benar atau bisa saja kurang teliti. 


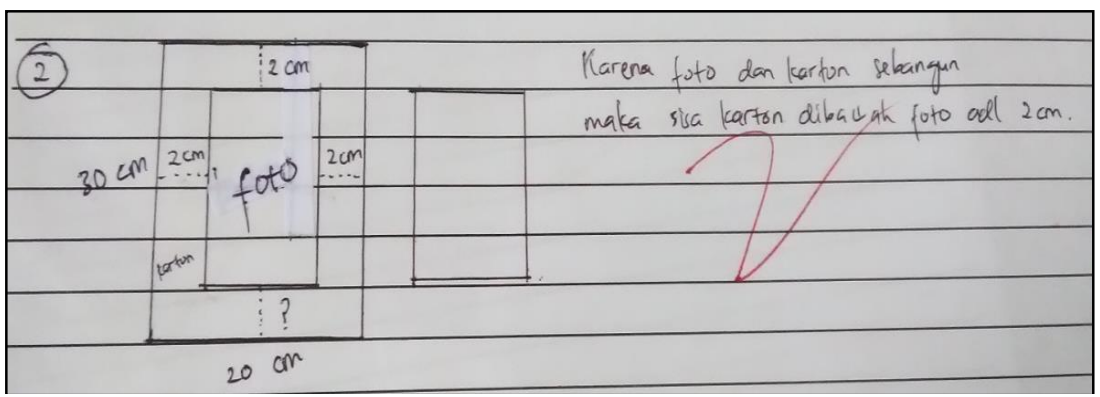

Gambar 5. Kesulitan S2 pada Jawaban No. 2

Berdasarkan Gambar 5 subjek S2 sudah menggambar model bangun dengan benar. Akan tetapi dia langsung memperoleh hasil yang belum tepat tanpa ada perhitungan sebelumnya. Kemungkinan S2 belum dapat menerapakan konsep kesebangunan dua bangun.

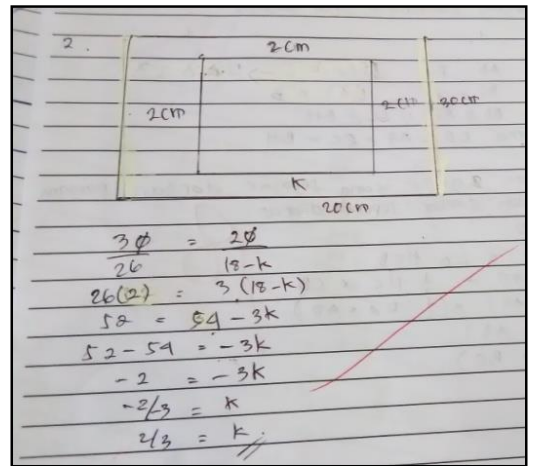

Gambar 6.Kesulitan S3 pada Jawaban No. 2

Berdasarkan Gambar 6 S3 sudah menggambar model bangun dengan benar. Akan tetapi, ketika menentukan panjang sisa karton menggunakan cara yang salah. Perbandingan yang digunakan belum tepat. Kemungkinan S3 belum bisa menerapkan konsep kesebangunan dua bangun.

Berdasarkan jawaban subjek S1, S2, dan S3, diperoleh kemungkinan bahwa subjek masih belum bisa menerapkan konsep kesebangunan secara benar. Mereka masih saja terbalik ketika menggunakan perbandingan ukuran sisi-sisi yang bersesuaian dari kedua bangun. 
c. Jawaban Soal Nomor 3

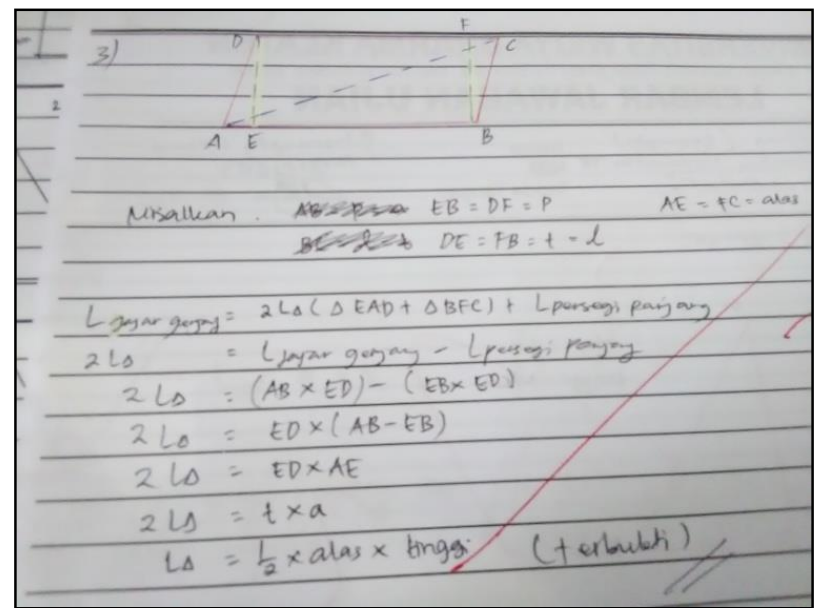

Gambar 7.Kesulitan S1 pada Jawaban No. 3

Berdasarkan Gambar 7 subjek S1 membuktikan rumus luas daerah segitiga dengan kombinasi pendekatan luas daerah jajargenjang dan persegipanjang. Padahal yang diminta di soal adalah membuktikan rumus luas daerah segitiga dengan pendekatan luas daerah jajargenjang. S1 juga membuktikannya dengan menggunakan segitiga siku-siku. Sedangkan yang diminta pada soal adalah segitiga sembarang. Jika hanya segitiga pada segitiga siku-siku, maka pembuktian tersebut belum tentu berlaku juga untuk segitiga sembarang.

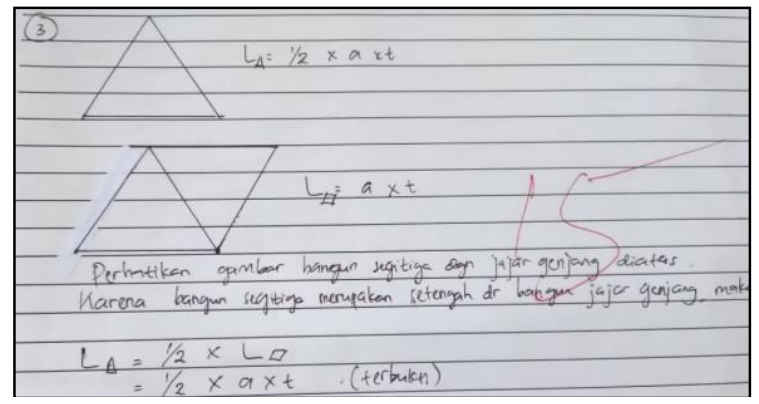

Gambar 8.Kesulitan S2 pada Jawaban No. 3

Berdasarkan Gambar 8 subjek S2 sudah menggunakan pendekatan luas daerah jajargenjang untuk membuktikan luas daerah segitiga, akan tetapi caranya masih belum lengkap. Strategi yang S3 gunakan sudah baik. Dia dapat mengonstruk dua segitiga yang kongruen yang disusun menjadi suatu bangun jajargenjang, tetapi dia tidak menuliskannya secara terperinci di jawabannya. 


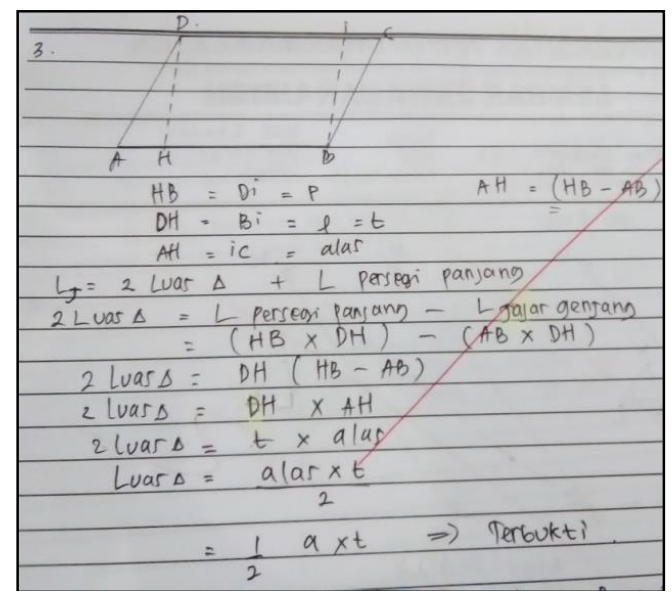

Gambar 9.Kesulitan S3 pada Jawaban No. 3

Berdasarkan Gambar 9 subjek S3 menggunakan cara yang sama dengan S1. S3 juga menggunakan kombinasi pendekatan luas daerah jajargenjang dan persegipanjang. Pembuktian juga menggunakan segitiga siku-siku, yang belum tentu berlaku juga segitiga sembarang.

Berdasarkan jawaban subjek S1, S2, dan S3 diperoleh kemungkinan bahwa mereka masih belum bisa membuktikan rumus luas daerah segitiga dengan menggunakan pendekatan luas daerah jajargenjang dengan benar. Kemungkinan mereka juga belum bisa melakukan analisis unsurunsur yang diketahui di soal dan menghubungkan unsur-unsur tersebut untuk disusun dalam suatu langkah-langkah yang sistematis untuk membuktikan suatu rumus.

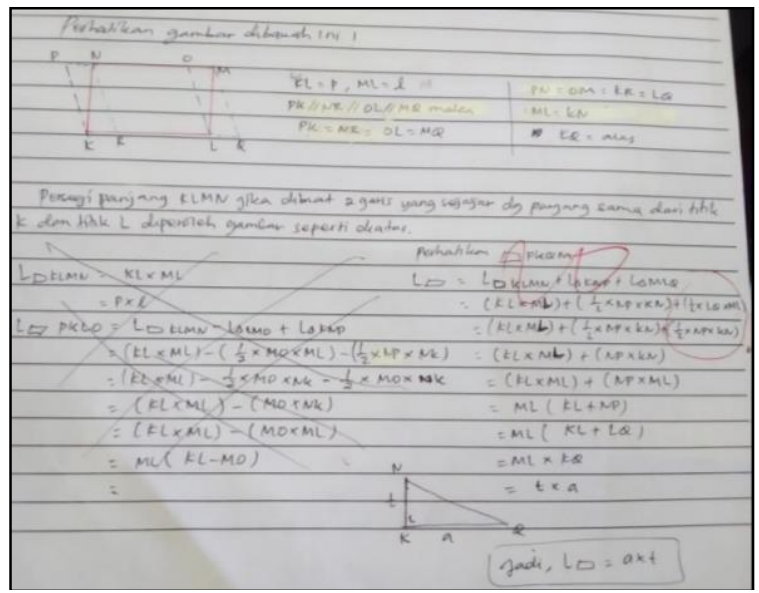

Gambar 10.Kesulitan S1 pada Jawaban No. 4 
Berdasarkan Gambar 10 subjek S1 tidak memilih salah satu pendekatan yang diberikan pada soal. S1 justru menggunakan dua pendekatan tersebut. Meskipun S1 berhasil membuktikan rumus luas daerah jajargenjang dengan dua pendekatan tersebut, tetapi dia belum memberikan penilaiannya tentang manakah pendekatan yang lebih efektif dari dua pendekatan yang diketahui.

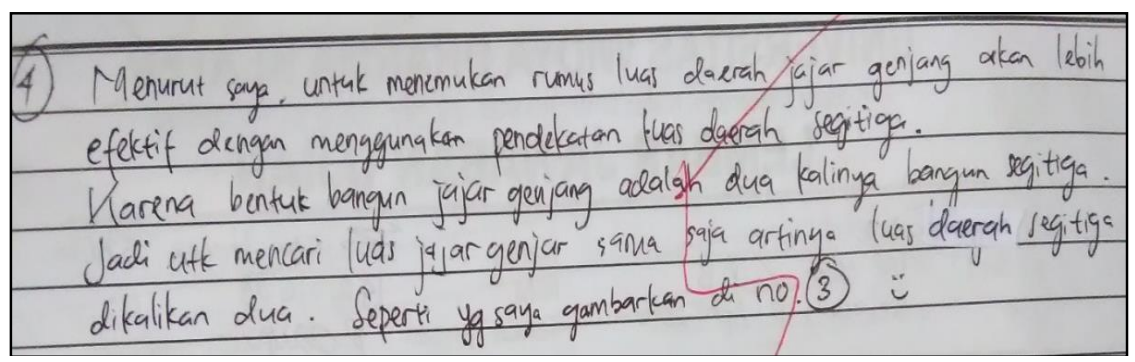

Gambar 11. Kesulitan S2 pada Jawaban No. 4

Berdasarkan Gambar 11 subjek S2 sudah memberikan penilaiannya. S1 memberikan peneilaian bahwa yang lebih efektif untuk membuktikan rumus luas daerah jajargenjang adalah dengan menggunakan pendekatan luas daerah segitiga. Penilaian yang diberikan S1 belum dapat dikatakan lengkap, karena tidak dilengkapi dengan data mendukung penilaiannya tersebut.

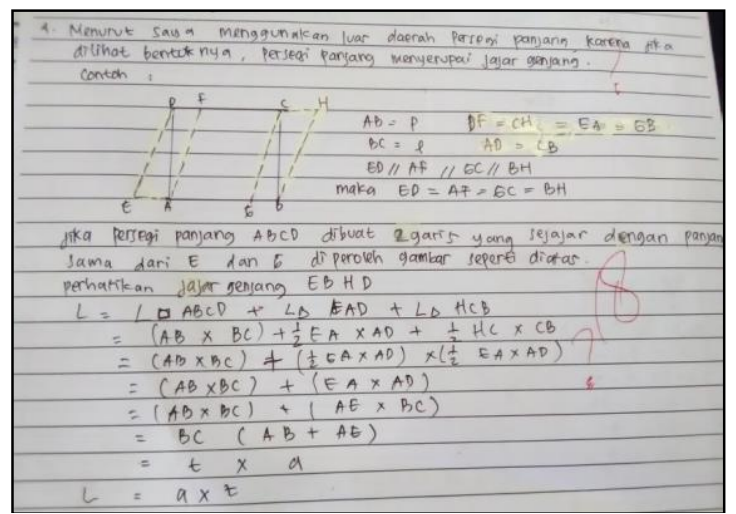

Gambar 12.Kesulitan S3 pada Jawaban No. 4

Berdasarkan Gambar 12 subjek S3 menjawab hampir sama dengan S1. S3 menggunakan dua pendekatan yang diberikan pada soal. S3 sudah memberikan penilaiannya tentang pendekatan yang lebih efektif, yaitu 
pendekatan luas daerah persegipanjang. Akan tetapi, alasan yang diberikannya belum logis.

Berdasarkan jawaban subjek S1, S2, dan S3 diperoleh kemingkinan bahwa mereka belum bisa memberikan penilaian terhadap suatu permasalahan dengan baik disertai dengan alasan yang logis dari penilaian yang diberikannya. Hal tersebut ditunjukkan dengan hanya terdapat satu subjek yang memberikan penilaiannya, akan tetapi itupun belum disertai dengan alasannya.

\section{Hasil Wawancara}

Tujuan diadakannya wawancara adalah untuk mengidentifikasi kesulitan mahasiswa, apakah sesuai dengan dugaan kesulitan pada hasil jawaban atau tidak. Berikut adalah hasil wawancara dengan ketiga subjek tersebut.

Hasil Wawancara dengan S1 Tentang Jawaban Soal Nomor 1

P : "Mengapa gambar jajagenjang KLMN Anda ubah menjadi gambar persegipanjang mbak?"

S1 : "Untuk mempermudah menentukan alas dan tinggi jajargenjang Pak."

P : : "Terus untuk apa dua segitiga siku-siku ini?"

S1 : "Dari persegipanjang itu saya pecah menjadi dua segitiga sikusiku, kemudian menentukan alas dan tingginya"

P : "Lalu menurut Anda apakah jajargenjang sama dengan persegipanjang?

S1 : "Beda Pak, hehe"

P : "Berarti cara Anda benar atau salah?"

S1 : " Saya bingung Pak kalau tidak dibuat persegipanjang dulu."

Hasil Wawancara dengan S2 Tentang Jawaban Soal Nomor 1

P : : "Dari jawaban Anda hanya disebutkan ada dua pasang alas dan tinggi jajargenjang saja ya mas?"

S2 : "lya Pak, untuk alas LM tinnginya NO dan alas KN tingginya LO."

P : : "Apakah menurut Anda KL dan MN bisa jadi alas mas?

S2 : "Tidak Pak, karena posisinya miring (tidak mendatar)"

P : "Jika posisinya saya putar sehingga $K L$ dan MN mendatar, apakah KL dan MN bisa jadi alas?"

S2 : "Oh iya ya Pak, bisa Pak." 
Hasil Wawancara dengan S3 Tentang Jawaban Soal Nomor 1

P : : "Mengapa Anda membuat diagonal untuk jajargenjang KLMN mbak"

S3 : "Untuk membuat segitiga siku-siku untuk membuat alas dan tinggi jajargenjang Pak"

P : : "Apakah Anda yakin kalau LN tegaklurus dengan MN?"

S3 : "lya Pak"

P : "Apakah gambar di soal jika dibuat diagonal juga bisa tegaklurus?"

S3 : : "Tidak Pak, kok saya jadi bingung ya Pak."

Hasil Wawancara dengan S1 Tentang Jawaban Soal Nomor 2

P : : "Apakah Anda sudah membaca soal nomor 2 dengan teliti?"

S1 : "Sudah Pak"

P : "Coba Anda lihat gambar pada jawaban Anda nomor 2 dan bandingkan dengan soalnya, apakah sesuai atau tidak?"

S1 : : "Oh, iya Pak, tidak sesuai. Waah, saya kurang teliti Pak."

P : : "Nah, itulah mengapa jawaban Anda saya salahkan, sebenarnya langkahnya sudah tepat, tapi kurang teliti."

S1 : "lya Pak"

Hasil Wawancara dengan S2 Tentang Jawaban Soal Nomor 2

P : "Mengapa Anda langsung memberikan jawaban untuk ukuran sisa bawah karton $2 \mathrm{~cm}$ mas?

S2 : "Menurut saya karena kedua bangun sebangun, maka ukuran sisa bawah karton sama dengan ukuran sisa karton di sisi atas, kanan dan kiri."

P : "Berarti ukuran tinggi foto berapa mas?"

S2 : "30-2 - $2=26 \mathrm{~cm}$ Pak."

$\mathrm{P} \quad$ : "Coba sekarang bandingkan tinggi foto dengan tinggi karton dan lebar foto dengan lebar karton, apakah nilal perbandingannya sama?"

S2 : "Kok tidak sama ya Pak?"

P : "Jadi apa kesimpulannya?"

S2 : "Jawaban saya salah ya Pak..."

P : "lya mas. Jadi, dua bangun dikatakan sebangun jika perbandingan ukuran sisi-sisi yang bersesuaian adalah sama."

S1 : "lya Pak......" 
Hasil Wawancara dengan S3 Tentang Jawaban Soal Nomor 2

P : "Mbak, apakah Anda tau akibat dari dua bangun datar yang sebangun?"

S3 : "Wah.... lupa saya Pak,...., "

$\mathrm{P} \quad$ : "Mengapa Anda menuliskan perbandingan seperti pada jawaban Anda?"

S3 : "Saya hanya mencoba membandingkan nilai yang besar dengan yang besar dan nilai yang kecil dengan yang kecil."

$\mathrm{P} \quad$ : "Apakah menurut mbak, 18 - $k$ memiliki nilai yang lebih kecil dari $20^{\prime \prime}$

S3 : "Iya Pak"

P : : "Bukannya tergantung nilai k nya mbak?"

S3 : "lya juga sih Pak."

P : : "Jadi kesimpulannya apa mbak?"

S3 : "Cara yang saya gunakan salah ya Pak?

P : "lya mbak. Jadi dua bangun dikatakan sebangun jika perbandingan ukuran sisi-sisi yang bersesuaian adalah sama, bukan asal membandingkan angka."

S3 : "Oooo gitu ya Pak"

P : "lya mbak begitu."

Hasil Wawancara dengan S1 Tentang Jawaban Soal Nomor 3

P : "Mbak, mengapa Anda menggunakan luas jajargenjang dan persegipanjang?"

S1 : "Untuk mempermudah mencari luas segitiga Pak"

$P \quad$ : "Bukannya di soal tertulis dengan pendekatan luas daerah jajaegenjang ya mbak?"

S1 : "lya sih Pak, emang.... tapi biar mudah aja Pak..."

$P \quad$ : "Segitiga yang anda buat itu segitiga siku-siku ya mbak"

S1 : "lya pak...."

$P \quad$ : "Bagaimana jika segitiga sembarang mbak"

S1 : "Belum tau saya Pak"

$P \quad$ : "Kalau segitiganya siku-siku apakah bisa diperumum untuk semua jenis segitiga mbak?"

S1 : "Ga tau saya Pak"

Hasil Wawancara dengan S2 Tentang Jawaban Soal Nomor 3 
P : "Anda membuat dua segitiga yang konkruen kemudian digabungkan menjadi jajargenjang ya mas?"

S2 : "lya Pak"

$\mathrm{P} \quad$ : "Lalu mengapa Anda bisa langsung menyimpulkan bahwa luas segitiga setengah dari luas jajargenjang?"

S2 : "Ya itu karena saya membuat dua segitiga yang konkruen lalu saya gabung sehingga membentuk jajargrenjang, sehingga saya langsung membuat kesimpulan seperti itu."

P : "Bisakah Anda mengerjakannya dengan menggunakan langkah yang lebih sistematis? Dengan menunjukkan mana alas dan tingginya?"

S2 : "Bentar Pak"

$\mathrm{P} \quad$ : "Ya"

S2 : "Gimana ya Pak? Saya kok bingung....., heee....."

Hasil Wawancara dengan S3 Tentang Jawaban Soal Nomor 3

P : "Mbak, maksud Anda menggunakan luas jajargenjang dan persegipanjang untuk apa?"

S3 : "Untuk mempermudah bagi saya menemukan rumus luas segitiga Pak"

P : "Segitiga yang Anda buat itu bukannya segitiga siku-siku ya mbak?"

S3 : "lya Pak"

$\mathrm{P} \quad$ : "Kalau untuk segitiga sembarang atau selain segitiga siku-siku bisa ga mbak?"

S3 : "Oh iya sih Pak. Saya bisanya itu Pak"

$\mathrm{P} \quad$ : "Yang diminta pada soal itu untuk segitiga sembarang mbak, tidak hanya segitiga siku-siku"

S3 : "lya Pak"

P : : "Sekarang perhatikan jawaban Anda pada persamaan pertama ke persamaan kedua, cek lagi apakah sudah benar yang Anda tuliskan itu?"

S3 : "Mana ya Pak?"

$\mathrm{P} \quad$ : "Yang luas persegipanjang dikurangi luas jajargenjang itu apakah benar? Bukannya Luas jajargenjangnya lebih besar daripada luas persegipanjangnya ya mbak?"

S3 : "Oh iya Pak. Persamaannya yang kedua kebalik Pak"

Hasil Wawancara dengan S1 Tentang Jawaban Soal Nomor 4 
P : : "Mbak, apakah Anda sudah memahami maksud soal nomor 4?"

S1 : "Sudah Pak"

P : "Maksud soal tersebut menyuruh Anda untuk memilih pendekatan mana yang lebih efetik untuk menemukan rumus luas daerah jajargenjang beserta alasannya. Lantas mengapa Anda malah menggunakan kedua pendatan tersebut"

S1 : "Kalau menuut saya justru malah lebih mudah jika menggunakan kedua pendekatan tesebut Pak"

P : "Kalau hanya menggunakan salah satu saja apakah bisa mbak?"

S1 : "Sepertinya bisa Pak, tapi ya kayaknya lebih gampang yang itu Pak"

P : : "Tapi Anda bisa membuktikannya jika hanya menggunakan satu pendekatan saja kan? Misalnya mengguanakan pendekatan luas persegipanjang saja gitu?"

S1 : "Sepertinya bisa Pak, cuma saya agak bingung saja Pak...."

Hasil Wawancara dengan S2 Tentang Jawaban Soal Nomor 4

P : "Menurut Anda, pendekatan yang lebih efektif untuk menemukan luas daerah jajargenjang adalah dengan menggunakanpendekatan luas daerah segitiga"

S2 : "Iya Pak"

$\mathrm{P} \quad$ : "Mengapa Anda tidak memilih menggunakan pendekatan luas daerah persegipanjang?"

S2 : "Ya itu Pak, karena jajargenjang itu dua kalinya segitiga, jika jajargenjang itu dipotong menurut salah satu diagonalnya."

P : "Jika menggunakan pendekatan luas daerah segitiga, lantas bagaimana langkah sistematisnya untuk menemukan rumus luas daerah segitiga? Kalau yang Anda sebutkan tadi kan secara langsung."

S2 : "Maksudnya bagaimana ya Pak? Saya masih belum paham"

P : :Maksudnya Anda gunakan pendekatan geometri dan aljabar untuk membuktikannya, sehingga dapat ketemu rumus luas daerah jajargenjang."

S2 : "Maaf Pak.. Saya kok merasa agak sulit kalau seperti itu."

Hasil Wawancara dengan S3 Tentang Jawaban Soal Nomor 4

P : : "Mbak, paada jawaban nomor 4, Anda memilih pendekatan luas persegipanjang karena menurut Anda persegipanjang menyerupai jajargenjang. Kira-kira mengapa bisa seperti itu ya Mbak?" 
S3 : "Ya mirip saja Pak, kan sama-sama mempunyai dua pasang sisi yang sejajar, sama panjang dan sudut yang saling berhadapan sama besar Pak"

P : "Kan kalau persegipanjang sudut yang saling berhadapan besarnya pasti 90 derajat, sedangkan jajargenjang ga mesti 90 derajat mbak?"

S3 : "lya sih Pak, ya kan hampir mirip saja Pak... hee...."

P : "Terus, jika Anda membuktikannya dengan pendektaan luas daerah persegipanjang, lantas mengapa Anda juga menggunakan luas daerah segitiga?"

S3 : "Ya biar lebih gampang aja Pak"

P : "Ya berarti Anda tidak konsiten dengan pernyataan awal di jawaban Anda tadi mbak."

S3 : "lya sih Pak"

Berdasarkan hasil wawancara dengan ketiga subjek diperoleh beberapa informasi sebagai berikut. Ketika mereka ditanya apa yang dimaksud dengan alas dan tinggi jajargenjang, mereka belum memberikan jawaban yang benar. Ada yang menjawab bahwa alas letaknya selalu di bawah suatu bangun, sementara tinggi meruapakan garis yang tegak lurus dengan alas. Jawaban tersebut tidaklah mutlak salah, akan tetapi kurang tepat. Sebenarnya setiap sisi pada jajargenjang bisa dijadikan sebagai alas, dengan tingginya adalah jarak antara setiap pasangan sisi yang saling sejajar. Ketika disuruh lagi untuk mengerjakan soal nomor 1 , semua subjek memberikan jawaban yang cenderung sama dengan jawaban awal. Berdasarkan informasi tersebut, dapat dikatakan bahwa subjek belum memahami konsep alas dan tinggi jajargenjang dengan benar.

Ketika ketiga subjek ditanyai tentang akibat dari dua bangun datar yang sebangun, ada yang menjawab perbandingan sisi-sisi yang bersesuaian senilai dan ada yang menjawab pula lupa. Padahal jawaban yang benar adalah perbandingan sisi-sisi yang bersesuaian senilai dan besar sudut-sudut yang bersesuaian sama besar. Saat disuruh menunjukkan sisi-sisi yang bersesuaian, mereka masih kebingungan untuk menunjukkannya. Hal inilah yang menyebabkan perbandingan mereka terbalik pada jawaban tes geometri. Berdasarkan informasi tersebut, dapat dikatakan bahwa subjek belum bisa menerapkan konsep kesebangunan bangun datar untuk menyelesaikan masalah dengan benar. 
Hasil wawancara dengan S2 tentang jawabannya pada soal nomor 3 adalah sebenarnya S2 sudah mempunyai ide awal untuk membuktikannya, yaitu dengan mengonstruk dua segitiga yang kongruen menjadi suatu bangun jajargenjang. Akan tetapi S2 merasa kesulitan untuk menguraikan idenya dalam pembuktian rumus tersebut, sehingga dia langsung menarik kesimpulan tanpa melalui tahapan atau langkahlangkah yang sistematis untuk membuktikannya. Subjek S1 dan S3 justru membuktikan rumus luas daerah segitiga dengan pendekatan luas daerah jajargenjang dan persegipanjang. Mereka merasa bingung jika membuktikannya hanya dengan pendekatan luas daerah jajargenjang seperti yang diminta pada soal.B erdasarkan informasi tersebut, dapat dikatakan bahwa subjek masih belum bisa menggunakan analisisnya untuk membuktikan rumus luas daerah segitiga dengan menggunakan pendekatan luas daerah jajargenjang. Mereka belum bisa melakukan analisis unsur-unsur yang diketahui di soal dan menghubungkan unsurunsur tersebut untuk disusun dalam suatu langkah-langkah yang sistematis untuk membuktikan suatu rumus.

Ketika subjek S1 ditanyai pendekatan manakah yang lebih efektif untuk membuktikan rumus luas daerah segitiga, dia merasa kebingungan. Menurut S1, kedua pendekatan tersebut seharusnya digunakan secara bersama-sama untuk membuktikan rumus luas daerah segitiga. S2 sudah memberikan penilaian beserta alasannya. Menurut S2, pendekatan yang lebih efektif adalah pendekatan luas daerah jajargenjang, karena bentuk jajargenjang merupakan dua kalinya bentuk segitiga. Alasan yang diberikan S2 belum didukung dengan data yang lengkap. Ketika ditanyai bagaimana cara membuktikan rumus tersebut dengan menggunakan pendekatan jajargenjang, dia langsung menujukkan bahwa jajargenjang bentuknya dua kali segitiga sehingga langsung menyimpulkan rumus luas daerah segitiga.

Subjek S3 sudah memberikan penilaian dan alasan. Menurutnya pendekatan yang lebih efektif adalah pendekatan luas daerah persegipanjang. Alasannya adalah persegipanjang bentuknya menyerupai jajargenjang. Maksudnya S3 adalah dari bentuk jajargenjang dibuat menjadi persegipanjang dengan cara memotong bagian jajargenjang berupa segitiga siku-siku kemudian ditempelkan di sebelah sisi lainnya sehingga terbentuk persegipanjang. Berdasarkan teknik tersebut, S3 
membuktikan rumus luas daerah segitiga. Akan tetapi, caranya tersebut berlaku untuk segitiga siku-siku yang belum temtu berlaku untuk segitiga sembarang. Ketika S3 ditanyai apakah cara tersebut berlaku untuk segitiga sembarang, dia kebingungan untuk menjawabnya. Berdasarkan hasil wawancara dengan subjek S1, S2 dan S3 tentang jawaban pada soal nomor 4, dapat dikatakan bahwa subjek masih belum bisa memberikan penilaian beserta alasan logisnya yang benar terhadap suatu permasalahan.

\section{Hasil Analisis dan Alternatif Pemecahannya}

Berdasarkan hasil jawaban soal tes geometri dan hasil wawancara dengan ketiga subjek didapatkan empat jenis kesulitan berdasarkan Taksonomi Bloom sebagai berikut.

1. Kesulitan pada Tingkat Pemahaman (Comprehension)

Mahasiswa mengalami kesulitan memahami dalam memahami konsep tinggi dan alas jajargenjang. Mahasiswa masih kesulitan menyebutkan pasangan alas dan tinggi jajargenjang secara benar. Alternatif pemecahan adalah dengan pembelajaran yang menggunakan model penilaian Assessment for Learning (AfL). Menurut Reform Assessment Group (ARG), sebagaimana dikutip oleh Flórez \& Sammons (2013), definisiAssessment for Learning (AfL) adalah penilaian apapun yang prioritas utama dalam desain dan praktik adalah untuk melayani tujuan mempromosikan pembelajaran murid. AfL merupakan suatu kegiatan penilaian dapat membantu belajar yang menyediakan informasi untuk digunakan sebagai umpan balik oleh guru, dan oleh murid mereka dalam menilai diri mereka sendiri dan satu sama lain, untuk mengubah kegiatan mengajar di mana mereka terlibat belajar. Hasil penelitian Mansyur (2011) menunjukkan bahwa (1) informasi yang diperoleh melalui penggunaan model-AfL akurat dan sesuai dengan kebutuhan nyata peserta didik; (2) penerapan model-AfL dalam pembelajaran matematika meningkatkan motivasi, kepercayaan diri, kesadaran diri, perilaku selama pembelajaran, dan kemampuan peserta didik terhadap matematika; serta (3) kemajuan belajar peserta didik ditampilkan melalui profil individu dan profil kelas. Hasil penelitian Isabwe, et. al. (2014) menunjukkan bahwa peserta didik merasa semangat terlibat dalam menilai kinerja matematika peserta didik lain, yaitu menilai jawaban tugas matematika sesama peserta didik. 


\section{Kesulitan pada Tingkat Penerapan (Comprehension)}

Mahasiswa kesulitan menerapkan konsep kesebangunan bangun datar untuk menyelesaikan masalah dengan benar. Mahasiswa kebingungan menyusun perbandingan sisi-sisi dua bangun yang bersesuaian. Alternatif pemecahannya adalah juga dengan pembelajaran yang menggunakan model penilaian AfL. Penerapan model AfL tersebut akan membantu mahasiswa mendapatkan umpan balik dari pekerjaannya yang belum benar, sehingga dapat mengetahui letak kesalahannya serta memperbaikinya. Mahasiswa diharapkan mampu mengidentifikasi sisi-sisi yang bersesuaian dan menyusun perbandingan senilai dari ukuran sisi-sisi yang bersuaian dari dua bangun datar yang sebangun.

3. Kesulitan pada Tingkat Analisis (Analysis)

Mahasiswa untuk membuktikan rumus luas daerah segitiga dengan menggunakan pendekatan luas daerah jajargenjang. Mereka belum bisa melakukan analisis unsur-unsur yang diketahui di soal dan menghubungkan unsur-unsur tersebut untuk disusun dalam suatu langkah-langkah yang sistematis untuk membuktikan suatu rumus. Alternatif penyelesaiannya adalah dengan pembelajaran Process Oriented Guided Inquiry Learning (POGIL). POGIL menggunakan inkuiri terbimbing, siklus pembelajaran eksplorasi, penemuan konsep, dan aplikasi sebagai dasar untuk banyak bahan yang dirancang dengan hati-hati yang menggunakan siswa untuk membimbing mereka untuk membangun pengetahuan baru. POGIL adalah strategi yang berpusat pada siswa, di mana siswa bekerja dalam kelompok kecil dengan peran individu untuk memastikan bahwa semua siswa sepenuhnya terlibat dalam proses pembelajaran. Kegiatan POGIL fokus pada konsep inti dan mendorong pemahaman yang mendalam tentang materi kuliah sambil mengembangkan keterampilan berpikir tingkat tinggi. POGIL mengembangkan keterampilan proses seperti berpikir kritis, pemecahan masalah, dan komunikasi melalui kerja sama dan refleksi, serta membantu siswa menjadi pembelajar seumur hidup dan mempersiapkan mereka untuk menjadi lebih kompetitif di pasar global. Hasil penelitian Rosidah (2013) menunjukkan bahwa pembelajaran dengan model POGIL berbantuan LKPD tuntas, serta kemampuan pemecahan masalah peserta didik pada model POGIL berbantuan LKPD lebih tinggi daripada 
kemampuan pemecahan masalah peserta didik pada pembelajaran konvensional.

4. Kesulitan pada Tingkat Evaluasi (Evaluation)

Mahasiswa mengalami kesulitan dalam memberikan penilaian terhadap suatu permasalahan dengan baik disertai dengan alasan yang logis dari penilaian yang diberikannya. Mahasiswa masih kesulitan dalam memberikan penilaian tentang manakah di antara pendekatan luas daerah persegipanjang dan jajargenjang yang lebih efektif digunakan untuk membuktikan atau menemukan rumus luas daerah segitiga. Alternatif pemecahannya adalah dengan pembelajaran yang menggunakan penilaian model peer-assesment. Menurut Falchikov, sebagaimana yang dikutip oleh Ako (2012), peer-assesment menuntut siswa untuk memberikan umpan atau nilai balik untuk rekan-rekan mereka pada produk atau kinerja, berdasarkan kriteria keunggulan untuk produk di mana siswa mungkin telah terlibat dalam menentukannya. Menurut Ako (2012), peer-assesment mempunyai kelebihan seperti berikut: (1) mendorong pembelajaran kolaboratif melalui pertukaran tentang apa yang merupakan pekerjaan yang baik; (2) siswa dapat saling membantu untuk memahami kesenjangan dalam pembelajaran dan pemahaman mereka dan untuk mendapatkan pemahaman yang lebih canggih dari proses pembelajaran; (3) siswa terlibat dalam komentarnya pada karya orang lain dapat meningkatkan kapasitas mereka sendiri untuk penilaian dan membuat pilihan intelektual; (4) siswa menerima umpan dari rekan-rekan mereka untuk bisa mendapatkan ide-ide lebih luas tentang pekerjaan mereka untuk mempromosikan pembangunan dan perbaikan; serta (5) membantu untuk mengurangi ketidakseimbangan kekuasaan antara guru dan siswa dan dapat meningkatkan status siswa dalam proses pembelajaran. Alasan pengambilan alternatif pemecahan tersebut juga didukung dengan hasil penelitian Chukwuyenum \& Adeleye (2013) menunjukkan bahwa peer assessment merupakan teknik yang baik untuk meningkatkan prestasi akademik siswa.

\section{Simpulan}

Hasil penelitian menunjukan bahwa terdapat empat kesulitan mahasiswa dalam menyelesaikan soal geometri berdasarkan Taksonomi Bloom berserta alternatif pemecahannya, yaitu: 
1. Kesulitan pada tingkat pemahaman, dimana mahasiswa mengalami kesulitan memahami dalam memahami konsep tinggi dan alas jajargenjang. Alternatif pemecahannya adalah dengan pembelajaran yang menggunakan model penilaian Assessment for Learning (AfL).

2. Kesulitan pada tingkat penerapan, dimana mahasiswa kesulitan menerapkan konsep kesebangunan bangun datar untuk menyelesaikan masalah dengan benar. Alternatif pemecahannya adalah juga dengan pembelajaran yang menggunakan model penilaian AfL.

3. Kesulitan pada tingkat analisis, dimana mahasiswa untuk membuktikan rumus luas daerah segitiga dengan menggunakan pendekatan luas daerah jajargenjang. Alternatif penyelesaiannya adalah dengan pembelajaran Process Oriented Guided Inquiry Learning (POGIL).

4. Kesulitan pada tingkat menilai, di mana mahasiswa mengalami kesulitan dalam memberikan penilaian terhadap suatu permasalahan dengan baik disertai dengan alasan yang logis dari penilaian yang diberikannya. Alternatif pemecahannya adalah dengan pembelajaran yang menggunakan penilaian model peer-assesment.

\section{Daftar Pustaka}

Abdussakir. (2009). Pembelajaran geometri sesuai Teori van Hiele. Jurnal Kependidikan dan Keagamaan, 7/2. Diakses di http://abdussakir.wordpress.com/2011/02/09/pembelajaran-geometrisesuai-teori-van-hiele-lengkap/. ISSN: 1693-1499.

Ako. W. W. (2012). Assessement matters: Self-assessment and peer assessment. Teaching Development, The University of Waikato.

Anderson, L. W.\& Krathwohl, D. R. (2001). Taxonomy for learning, teaching and assessing: a revision of Bloom's taxonomy of educationalobjectives. New York: Longman.

Budiyono. (2015). Pengantar penilaian hasil belajar. Surakarta: UNS PRESS.

Chukwuyenum, A. N. \& Adeleye.(2013). Impact of peer assessment on performance in mathematics among senior secondary school students in Delta State, Nigeria.Journal of Emerging Trends in Educational Research and Policy Studies (JETERAPS). 4/5, 719-725. ISSN: 2141-6990. Diakses di http://jeteraps.scholarlinkresearch.com/articles/Impact\%20of\%20Peer\%2 $\underline{\text { OAssessment.pdf }}$

Flórez, M. T. \& Sammons, P. (2013). Assessment for Learning: Effect and impact. Oxford University Department of Education. 
Imswatama, A. \& Muhassanah, N. (2015). Analisis kesulitan mahasiswa dalam menyelesaikan soal geometri analitik bidang materi garis dan lingkaran. Prosiding Seminar Matematika dan Pendidikan Matematika UNY 2015. Universitas Negeri Yogyakarta-Yogyakarta, 41-48.

Isabwe, G. M. N., Reichert, F., Carlsen, M., \& Lian, T. A. (2014).Using assessment for learning mathematics with mobile tablet based solutions. International Journal of Emerging Technologies in Learning, 9/2, 2936.ISSN: 1863-0383.Diakses di:http://online-journals.org/index.php/ijet/article/view/3219.

Mansyur. (2011). Pengembangan model assessment for learning pada pembelajaran matematika di SMP. Jurnal Penelitian dan Evaluasi Pendidikan, 151/, 71-91.Diakses di: http://journal.uny.ac.id/index.php/jpep/article/download/1088/1140.

Moleong, L. J. (2007). Metodologi penelitian kualitatif. Bandung: PT Remaja Rosdakarya.

Piaget, J. (2002). The principles of genetic epistemology. London and New York: ROUTLEDGE.

Process Oriented Guided Inquiry Learning (2012). Diakses di http://www.pogil.org.

Radita, N. (2015). Diagnosis Kesulitan mahasiswa pada mata kuliah geometri analitik berdasarkan taksonomi Bloom dan pelaksanaan scaffolding-nya (Master Thesis). Diakses di: http://karyailmiah.um.ac.id/index.php/disertasi/article/view/42700.

Rosidah. (2013). Keefektifan pembelajaran POGIL berbantuan LKPD terhadap kemampuan pemecahan masalah materi pokok peluang. Jurnal Kreano. 4/1, 73-79. ISSN: 2086-2334. Diakses di: http://lib.unnes.ac.id/18712/1/4101408103.pdf

Suprijono, A. (2013). Cooperative learning: teori \& aplikasi PAIKEM. Yogyakarta: Pustaka Pelajar.

Yuliani \& Sumardi. (2015). Kesulitan melukis, memahami lingkaran dalam dan luar segitiga pada mahasiswa semester 1 pendidikan matematika. Prosiding Seminar Nasional Matematika dan Pendidikan Matematika UMS 2015. Universitas Muhammadiyah Surakarta-Surakarta, 172-178. 